\title{
Prediction of Electroconvulsive Therapy Response and Remission in Major Depression: Meta-analysis - CORRIGENDUM
}

Linda van Diermen, Seline van den Ameele, Astrid M. Kamperman, Bernard C.G. Sabbe, Tom Vermeulen, Didier Schrijvers and Tom K. Birkenhäger

\section{Summary}

This notice describes a correction to the above mentioned paper.

\section{Copyright and usage}

(c) The Royal College of Psychiatrists 2018. https://doi.org/10.1192/bjp.2017.28, Published by Cambridge University Press 1 February 2018.

In the original publication of this review article $^{1}$ the author affiliations were incorrectly stated for Linda van Diermen, Bernard C. G. Sabbe and Tom Vermeulen. The correct author affiliations for these authors are CAPRI, Department of Biomedical Sciences, University of Antwerp, Belgium and University Department, Psychiatric Hospital Duffel, VZW Emmaüs, Duffel, Belgium.

The affiliations have been corrected in both the online PDF and HTML versions of this article. The author apologises for these errors.
Linda van Diermen, Seline van den Ameele, Astrid M. Kamperman, Bernard C. G. Sabbe, Tom Vermeulen, Didier Schrijvers, Tom K. Birkenhäger

\section{Reference}

1. Van Diermen $L$, Van den Ameele $S$, Kamperman $A$, Sabbe B, Vermeulen $T$, Schrijvers $D$, Birkenhäger T. Prediction of electroconvulsive therapy response and remission in major depression: Meta-analysis. The British Journal of Psychiatry 2018; 212(2): 71-80. 